\title{
DNA binding and oxidative cleavage activity of ternary (L-proline)copper(II) complexes of heterocyclic bases
}

\author{
Ramakrishna Rao ${ }^{\text {a }}$, Ashis K. Patra ${ }^{\text {b }}$, P.R. Chetana ${ }^{\text {a,* }}$ \\ a Department of Chemistry, Central College Campus, Bangalore University, Bangalore 560 001, India \\ ${ }^{\mathrm{b}}$ Department of Inorganic and Physical Chemistry, Indian Institute of Science, Sir C. V. Raman Avenue, Bangalore 560012 , India
}

Received 26 May 2007; received in revised form 28 July 2007; accepted 29 July 2007

Available online 11 September 2007

\begin{abstract}
Ternary copper(II) complexes $\left[\mathrm{Cu}(\mathrm{L}-\right.$ pro $\left.)(\mathrm{B})\left(\mathrm{H}_{2} \mathrm{O}\right)\right]\left(\mathrm{NO}_{3}\right)(\mathbf{1}, \mathbf{2})$ where L-pro = L-proline, B is a N,N-donor heterocyclic base, viz. 2,2'bipyridine (bpy, 1), 1,10-phenanthroline (phen, 2), are synthesized, characterized, and their DNA binding and cleavage activity studied. The bpy complex (1) is structurally characterized by single-crystal X-ray crystallography. The complexes show the presence of a distorted square-pyramidal $(4+1) \mathrm{CuN}_{3} \mathrm{O}_{2}$ coordination geometry. Complex $\left[\mathrm{Cu}(\mathrm{L}-\right.$ pro $)($ bpy $\left.)\left(\mathrm{H}_{2} \mathrm{O}\right)\right]\left(\mathrm{NO}_{3}\right)(\mathbf{1})$ crystallizes in the triclinic space group $P 1$ with unit cell parameters: $a=7.082(3) \AA \circ, b=10.483(5) \AA, c=11.581(5) \AA, \alpha=89.700(7)^{\circ}, \beta=83.488(8)^{\circ}, \gamma=84.109(8)^{\circ}$ and $V=849.7(7) \AA^{3}$. The one-electron paramagnetic complexes display a d-d band near $600 \mathrm{~nm}$ in water and show a cyclic voltammetric response due to $\mathrm{Cu}(\mathrm{II}) / \mathrm{Cu}(\mathrm{I})$ couple near $0.1 \mathrm{~V}$ (versus SCE) in Tris- $\mathrm{HCl}$ buffer- $0.1 \mathrm{M} \mathrm{KCl}$. Binding interactions of the complexes with calf thymus (CT) DNA have been investigated by emission, absorption, viscosity and DNA thermal denaturation studies. The phen complex displays significant binding propensity to the CT DNA giving an order: $\mathbf{2}$ (phen) $\gg \mathbf{1}$ (bpy). The bpy complex does not show any apparent binding to the DNA and hence poor cleavage efficiency. Complex 2 shows efficient oxidative cleavage of SC-DNA in the presence of 3-mercaptopropionic acid (MPA) involving hydroxyl radical species as evidenced from the control data showing inhibition of DNA cleavage in the presence of DMSO and catalase.
\end{abstract}

(C) 2007 Elsevier Ltd. All rights reserved.

Keywords: Copper; DNA binding; DNA cleavage; Crystal structure; L-Proline; Phenanthroline base

\section{Introduction}

Compounds cleaving DNA under physiological conditions are of current interests for their potential applications in genomic research and as footprinting and therapeutic agents [1-10]. The DNA cleavage could occur by two major pathways, viz. hydrolytic and oxidative pathways. Hydrolytic DNA cleavage involves cleavage of phosphoester bond to generate fragments those could be subsequently religated. Hydrolytic cleavage active species mimics restriction enzymes. The oxidative DNA cleavage involves either oxidation of the deoxyribose moiety by abstraction of sugar hydrogen or oxidation of nucleobases. The purine

\footnotetext{
* Corresponding author. Tel.: +91 080 22961353; fax: +91 8022386988. E-mail address: pr.chetana@gmail.com (P.R. Chetana).
}

base guanine is most susceptible for oxidation among four nucleobases. The role of ternary copper(II) complexes in biological systems is well known [11]. Among the transition metal based DNA cleaving agents, particularly copper phenanthroline complexes, is primarily sugar directed. They are responsible for direct strand scission by hydrogen atom abstraction from the deoxyribose moiety. Sigman and co-workers have reported that the bis-(1,10-phenanthroline)copper(I) complex in presence of $\mathrm{H}_{2} \mathrm{O}_{2}$ acts as a 'chemical nuclease' that efficiently nicks DNA [1,2]. Recently there are several reports of copper(II) complexes showing efficient chemical nuclease activity [12-15]. Recent reports have also shown that amino acid/peptide based copper(II) complexes show efficient DNA cleavage activity by oxidative and hydrolytic pathways [15-21].

The present work stems from our interest to design ternary copper(II) complexes of bio-essential $\alpha$-amino acid 
L-proline and N,N-donor heterocyclic bases as DNA groove binders. Our choice of 2,2'-bipyridine (bpy) and 1,10-phenathroline (phen) is based on their difference in DNA binding ability $[13,15 \mathrm{c}]$. The distinctive cyclic structure of proline's side chain gives an exceptional conformational rigidity compared to other amino acids. L-proline is essential for the synthesis of collagen, the most abundant protein in mammals [22].

Herein, we present the synthesis, structure, DNA binding and cleavage property of two ternary copper(II) complexes of formulation $\left[\mathrm{Cu}(\mathrm{L}-\mathrm{pro})(\mathrm{B})\left(\mathrm{H}_{2} \mathrm{O}\right)\right]\left(\mathrm{NO}_{3}\right)(\mathbf{1}$, 2) where $\mathrm{B}$ is $\mathrm{N}, \mathrm{N}$-donor heterocyclic base, viz. 2,2'bipyridine (bpy, 1) and 1,10-phenanthroline (phen, 2) (Scheme 1). The bpy complex (1) has been structurally characterized by X-ray crystallography. Detailed studies have been made to elucidate the role of the DNA binder and the mechanistic pathways involved in the "chemical nuclease' activity.

\section{Experimental}

\subsection{Materials}

All reagents and chemicals were procured from commercial sources. Solvents used for electrochemical and spectroscopic studies were purified by standard procedures [23]. The supercoiled pUC19 DNA (cesium chloride purified) was purchased from Bangalore Genei (India). Calf thymus (CT) DNA, agarose (molecular biology grade), distamycinA, catalase, superoxide dismutase (SOD) and ethidium bromide (EB) were obtained from Sigma (USA). Tris(hydroxymethyl)aminomethane- $\mathrm{HCl}$ (Tris- $\mathrm{HCl}$ ) buffer solution was prepared by using deionized, sonicated triple distilled water.

\subsection{Synthesis}

Preparation of $\left[\mathrm{Cu}(\mathrm{L}-\right.$ pro $\left.)(\mathrm{B})\left(\mathrm{H}_{2} \mathrm{O}\right)\right]\left(\mathrm{NO}_{3}\right) \quad(\mathbf{1}, \quad 2)$ ( $B=b p y$, phen). The complexes were prepared by following a reported [24] synthetic method with modification in

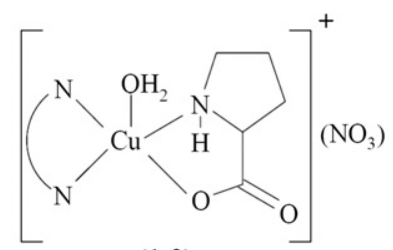

$(1-2)$
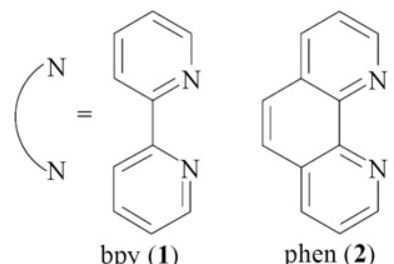

Scheme 1. Complexes $\mathbf{1}$ and $\mathbf{2}$ and the heterocyclic bases. which a $10 \mathrm{ml}$ aqueous solution of $\mathrm{Cu}\left(\mathrm{NO}_{3}\right)_{2} \cdot 3 \mathrm{H}_{2} \mathrm{O}$ $(0.48 \mathrm{~g}, 2.0 \mathrm{mmol})$ was reacted with L-proline $(0.23 \mathrm{~g}$, $2.0 \mathrm{mmol})$ treated with $\mathrm{NaOH}(0.08 \mathrm{~g}, 2.0 \mathrm{mmol})$ in water $(10 \mathrm{ml})$ under magnetic stirring at room temperature. After $30 \mathrm{~min}$, a $20 \mathrm{ml}$ methanol solution of the heterocyclic base [bpy $(0.31 \mathrm{~g})$, phen $(0.40 \mathrm{~g})(2.0 \mathrm{mmol})]$ was added to the solution and the resulting mixture was stirred for $2 \mathrm{~h}$ at room temperature. On cooling the solution to an ambient temperature, it was filtered and the filtrate on slow concentration yielded crystalline solid of the product. The solid was isolated and washed with cold aqueous methanol and finally dried over $\mathrm{P}_{4} \mathrm{O}_{10}$ (yield: $\sim 70 \%$ ). Anal. Calc. for $\mathrm{C}_{15} \mathrm{H}_{18} \mathrm{CuN}_{4} \mathrm{O}_{6}(\mathbf{1})$ : C, 43.52; H, 4.38; N, 13.53. Found: C, 43.35; H, 4.18; N, $13.26 \%$. $\lambda_{\max }, \mathrm{nm}\left(\varepsilon, \mathrm{M}^{-1} \mathrm{~cm}^{-1}\right)$ in water: 602 (50), 311 (10820), 300 (10790), 237sh (11030). FT-IR, $\mathrm{cm}^{-1}$ (KBr disc): 3445br, 3238m, 3018m, 2946m, $2885 \mathrm{~s}, 1627 \mathrm{~s}, 1574 \mathrm{w}, 1448 \mathrm{~m}, 1384$ vs, $1287 \mathrm{w}, 1191 \mathrm{~m}$, $1046 \mathrm{~m}, 922 \mathrm{~m}, 835 \mathrm{~m}, 786 \mathrm{~m}, 733 \mathrm{~s}, 662 \mathrm{~m}, 576 \mathrm{~m}, 518 \mathrm{~m}$, $421 \mathrm{~m}$ (s, strong; m, medium; w, weak; br, broad; vs, very strong). $\mu_{\mathrm{eff}}$ (solid, $\left.298 \mathrm{~K}\right): 1.78 \mu_{\mathrm{B}} . \Lambda_{\mathrm{M}}\left(\Omega^{-1} \mathrm{~cm}^{2} \mathrm{M}^{-1}\right)$ in water at $25^{\circ} \mathrm{C}$ : 128. Anal. Calc. for $\mathrm{C}_{17} \mathrm{H}_{18} \mathrm{CuN}_{4} \mathrm{O}_{6}$ (2): C, 46.61; H, 4.15; N, 12.79. Found: C, 46.35; H, 4.07; N, $12.58 \% . \lambda_{\max }, \mathrm{nm}\left(\varepsilon, \mathrm{M}^{-1} \mathrm{~cm}^{-1}\right)$ in water: $612(60), 294$ (8740), 272 (29350), 204 (38 800). FT-IR, $\mathrm{cm}^{-1}$ (KBr disc): $3380 \mathrm{br}, 3150 \mathrm{br}, 2884 \mathrm{~m}, 1624 \mathrm{~s}, 1519 \mathrm{~m}, 1519 \mathrm{~m}, 1387 \mathrm{vs}$, $1327 \mathrm{w}, 1148 \mathrm{~m}, 1041 \mathrm{~m}, 932 \mathrm{~m}, 859 \mathrm{~s}, 825 \mathrm{~m}, 780 \mathrm{~m}, 724 \mathrm{~s}$, $628 \mathrm{w}, 582 \mathrm{w}, 531 \mathrm{~m}, 468 \mathrm{~m}, 430 \mathrm{w} . \quad \mu_{\mathrm{eff}}$ (solid, $298 \mathrm{~K}$ ): $1.75 \mu_{\mathrm{B}} . \Lambda_{\mathrm{M}}\left(\Omega^{-1} \mathrm{~cm}^{2} \mathrm{M}^{-1}\right)$ in water at $25^{\circ} \mathrm{C}: 190$.

The complexes showed high solubility in water, good solubility in methanol and ethanol, dimethylformamide (DMF) and dimethyl sulfoxide (DMSO) and were insoluble in hydrocarbons.

\subsection{General methods}

The elemental analysis was done using a Thermo Finnigan FLASH EA 1112 CHNS analyzer. The infrared and electronic spectra were recorded on Perkin-Elmer Lambda 35 and Perkin-Elmer spectrum one 55 spectrophotometers, respectively. DNA melting experiments were carried out on a Varian Cary 300 Bio UV-Vis spectrophotometer attached to a Cary Peltier temperature controller. Magnetic susceptibility data at $298 \mathrm{~K}$ for the polycrystalline samples of the complexes were obtained using Model 300 Lewis-coil-force magnetometer of George Associates Inc. (Berkeley, USA) make. $\mathrm{Hg}\left[\mathrm{Co}(\mathrm{NCS})_{4}\right]$ was used as a standard. Experimental susceptibility data were corrected for diamagnetic contributions [25]. Molar conductivity measurements were done using a Control Dynamics (India) conductivity meter. Electrochemical measurements were made at $25^{\circ} \mathrm{C}$ on an EG\&G PAR model 253 VersaStat potentiostat/galvanostat with electrochemical analysis software 270 using a three electrode setup consisting of a glassy carbon working, platinum wire auxiliary and a saturated calomel reference electrode (SCE) in water containing $0.1 \mathrm{M} \mathrm{KCl}$. The electrochemical data were uncorrected for junction potentials. 


\subsection{X-ray crystallographic procedures}

Dark-blue single crystals of $[\mathrm{Cu}$ (L-pro)(bpy)$\left.\left(\mathrm{H}_{2} \mathrm{O}\right)\right]\left(\mathrm{NO}_{3}\right)$ (1) was obtained on slow concentration of the aqueous-methanolic solution of the complex. Crystal mounting was done on glass fiber with epoxy cement. All geometric and intensity data for $\mathbf{1}$ were collected at room temperature using a Bruker SMART APEX CCD diffractometer, equipped with a fine focus $1.75 \mathrm{~kW}$ sealed tube Mo K $\alpha$ X-ray source $(\lambda=0.71073 \AA)$, with increasing $\omega$ (width of $0.3^{\circ} /$ frame) at a scan speed of $10 \mathrm{~s} /$ frame. The SMART software was used for data acquisition and the SAINT software for data extraction. Absorption corrections were made using SADABS [26]. The structure was solved and refined by full-matrix least-squares method using sHELX system of programs [27]. All non-hydrogen atoms were refined anisotropically. The hydrogen atoms attached to the heteroatoms were fixed in their calculated positions and refined using a riding model.

Crystal data for 1: Formula: $\mathrm{C}_{15} \mathrm{H}_{18} \mathrm{CuN}_{4} \mathrm{O}_{6}$; colour: blue; size: $0.32 \times 0.26 \times 0.20 \mathrm{~mm} ; \quad M=413.87$; triclinic, space group $P 1$ (no. 1); $a=7.082(3) ; b=10.483(5) ; c=$ 11.581(5) $\AA ; \alpha=89.700(7) ; \beta=83.488(8) ; \gamma=84.109(8)^{\circ}$; $V=849.7(7) \AA^{3} ; Z=2 ; T=293(2) \mathrm{K} ; D_{c}=1.618 \mathrm{~g} \mathrm{~cm}^{-3}$; $\mu=13.27 \mathrm{~cm}^{-1} ; 1.77 \leqslant 2 \theta \leqslant 26.37 ; R\left(F_{\mathrm{o}}\right)=0.0588 ; w R=$ 0.1420 for 6550 reflections with $I>2 \sigma(I)$ and 469 parameters. $\left[R_{1}\left(F^{2}\right)=0.0714\right.$ (all data)]; weighing scheme: $w=1 /$ $\left[\sigma^{2}\left(F_{\mathrm{o}}^{2}\right)+0.0852 P^{2}+0.0 P\right]$, where $P=\left(F_{\mathrm{o}}^{2}+2 F_{\mathrm{c}}^{2}\right) / 3$. The goodness-of-fit and the largest difference peak were 1.020 and $1.080 \mathrm{e}^{-3}$, respectively. Perspective view of the complex was obtained by ORTEP [28].

\subsection{Studies on DNA interaction}

The UV absorbance at 260 and $280 \mathrm{~nm}$ of the CT-DNA solution in $5 \mathrm{mM}$ Tris- $\mathrm{HCl}$ buffer ( $\mathrm{pH}$ 7.2) gave a ratio of $\sim 1.9$, indicating the DNA was free of protein [29]. The concentration of CT DNA was measured from the band intensity at $260 \mathrm{~nm}$ with a known $\varepsilon$ value $\left(6600 \mathrm{M}^{-1} \mathrm{~cm}^{-1}\right)$ [30]. The electronic spectra of the complexes were recorded before and after addition of CT-DNA in the $5 \mathrm{mM}$ Tris$\mathrm{HCl} / 5 \mathrm{mM} \mathrm{NaCl}$ buffer ( $\mathrm{pH}$ 7.2). The equilibrium binding constant $\left(K_{\mathrm{b}}\right)$ values for the interaction of the complexes with CT-DNA were obtained from the absorption spectral titration data using the following equation:

$\left(\varepsilon_{\mathrm{a}}-\varepsilon_{\mathrm{f}}\right) /\left(\varepsilon_{\mathrm{b}}-\varepsilon_{\mathrm{f}}\right)=\left(b-\left(b^{2}-2 K_{\mathrm{b}}^{2} C_{\mathrm{t}}[\mathrm{DNA}] / s\right)^{1 / 2}\right) / 2 K_{\mathrm{b}} C_{\mathrm{t}}$

where $b=1+K_{\mathrm{b}} C_{\mathrm{t}}+K_{\mathrm{b}}[\mathrm{DNA}] / 2 s ; \varepsilon_{\mathrm{a}}$, the extinction coefficient observed for the charge transfer absorption band at a given DNA concentration; $\varepsilon_{\mathrm{f}}$, the extinction coefficient of the complex free in solution; $\varepsilon_{\mathrm{b}}$, the extinction coefficient of the complex when fully bound to DNA; $K_{\mathrm{b}}$, the equilibrium binding constant; $C_{\mathrm{t}}$, the total metal complex concentration; [DNA], the DNA concentration in nucleotides; and $s$, the binding site size in base pairs $[31,32]$.
The apparent binding constant $\left(K_{\mathrm{app}}\right)$ of the complexes 1 and $\mathbf{2}$ were also determined by fluorescence spectral technique using ethidium bromide (EB) bound CT DNA solution in Tris- $\mathrm{HCl} / \mathrm{NaCl}$ buffer $(\mathrm{pH}$ 7.2). The fluorescence intensities of EB at $600 \mathrm{~nm}$ (546 nm excitation) with an increasing amount of the ternary complex concentration were recorded. Ethidium bromide was non-emissive in Tris-buffer medium due to fluorescence quenching of the free EB by the solvent molecules $[33,34]$. In the presence of DNA, EB showed enhanced emission intensity due to its intercalative binding to DNA. A competitive binding of the copper complexes to CT DNA could result in the displacement of EB or quenching of the bound EB by the paramagnetic copper(II) species decreasing its emission intensity.

DNA-melting experiments were carried out by monitoring the absorbance of CT-DNA $(200 \mu \mathrm{M} \mathrm{NP})$ at $260 \mathrm{~nm}$ with varying temperature in the absence and presence of the complexes in a 2:1 ratio of DNA and the complex with a ramp rate of $0.5^{\circ} \mathrm{C} / \mathrm{min}$ in phosphate buffer $(\mathrm{pH}$ 6.85) using a Peltier system attached to the UV-Vis spectrophotometer.

Viscometric titrations were performed with a Schott Gerate AVS 310 Automated Viscometer. The viscometer was thermostated at $37{ }^{\circ} \mathrm{C}$ in a constant temperature bath. The concentration of DNA was $200 \mu \mathrm{M}$ in NP and the flow times were measured with an automated timer, and each sample was measured three times, and an average flow time was calculated. Data were presented as $\left(\eta / \eta_{0}\right)^{1 / 3}$ vs. [complex $] /[\mathrm{DNA}]$, where $\eta$ is the viscosity of DNA in the presence of complex and $\eta_{0}$ that of DNA alone. Viscosity values were calculated from the observed flowing time of DNA-containing solutions $(t)$ corrected for that of buffer alone $\left(t_{0}\right), \eta=\left(t-t_{0}\right)$.

\subsection{DNA cleavage}

The extent of cleavage of supercoiled (SC) DNA in the presence of the complex and reducing agent MPA was determined by agarose gel electrophoresis. In a typical reaction, supercoiled pUC19 DNA $(0.2 \mu \mathrm{g})$, taken in $50 \mathrm{mM}$ Tris- $\mathrm{HCl}$ buffer (pH 7.2) containing $50 \mathrm{mM} \mathrm{NaCl}$, was treated with the complex. The extent of cleavage was measured from the intensities of the bands using UVITEC Gel Documentation System.

For mechanistic investigations, inhibition reactions were done on adding the reagents prior to the addition of the complex. The solutions were incubated for $1 \mathrm{~h}$ in a dark chamber at $37{ }^{\circ} \mathrm{C}$ followed by addition to the loading buffer containing $25 \%$ bromophenol blue, $0.25 \%$ xylene cyanol, and $30 \%$ glycerol $(2 \mu \mathrm{L})$, and the solution was finally loaded on $0.8 \%$ agarose gel containing $1.0 \mu \mathrm{g} / \mathrm{ml}$ ethidium bromide (EB). Electrophoresis was carried out for $2 \mathrm{~h}$ at $60 \mathrm{~V}$ in tris-acetate-EDTA (TAE) buffer. Bands were visualized by UV light and photographed for analysis. Due corrections were made to the observed intensities for the low level of $\mathrm{NC}$ form present in the original sample of $\mathrm{SC}$ 
DNA and for the low affinity of EB binding to SC in comparison to nicked-circular (NC) and linear forms of DNA [35].

\section{Results and discussion}

\subsection{Synthesis and general aspects}

The ternary copper(II) complexes are prepared in high yield from the reaction of $\mathrm{Cu}\left(\mathrm{NO}_{3}\right)_{2} \cdot 3 \mathrm{H}_{2} \mathrm{O}$ with L-proline and heterocyclic bases. The complexes are stable and soluble in water and common polar organic solvents. They are characterized from the analytical and physicochemical data (Table 1). The one-electron paramagnetic complexes display intense charge transfer (CT) band in the range of $200-320 \mathrm{~nm}$ that can be attributed to the $\pi \rightarrow \pi^{*}$ transition of the coordinated phenanthroline ligand. The $\mathrm{d}-\mathrm{d}$ band is observed at $\sim 600 \mathrm{~nm}$ in an aqueous medium (Fig. 1). The complexes are redox active and display a cyclic voltammetric response near $0.1 \mathrm{~V}$ versus $\mathrm{SCE}$ in water- $0.1 \mathrm{M} \mathrm{KCl}$. The redox process is assignable to the $\mathrm{Cu}(\mathrm{II}) / \mathrm{Cu}(\mathrm{I})$ couple. The complexes show 1:1 electrolytic behavior in solution.

\subsection{Crystal structure of 1}

Complex 1 has been structurally characterized from single-crystal X-ray diffraction technique. It crystallizes in the non-centrosymmetric $P 1$ space group of the triclinic crystal system having two independent molecules in the crystallographic asymmetric unit. The copper(II) ion is coordinated in a distorted square-pyramidal $(4+1)$ coordination geometry through the carboxylate oxygen atom $\mathrm{O}(1)$ and the amino nitrogen atom $\mathrm{N}(3)$ of L-proline and two N-atoms of 2,2'-bipyridine and a weakly bound apical water mole-

Table 1

Physicochemical data for the ternary L-proline copper(II) complexes 1 and 2

\begin{tabular}{lll}
\hline Complex & $\mathbf{1}(\mathrm{B}=$ bpy $)$ & $\mathbf{2}(\mathrm{B}=$ phen $)$ \\
\hline $\mathrm{IR}^{\mathrm{a}}:\left[v\left(\mathrm{NO}_{3}^{-}\right) / \mathrm{cm}^{-1}\right]$ & 1384 & 1387 \\
$\left.\mathrm{~d}-\mathrm{d} \mathrm{Band:} \lambda_{\max } / \mathrm{nm}^{-1} / \mathrm{M}^{-1} \mathrm{~cm}^{-1}\right)^{\mathrm{b}}$ & $602(50)$ & $612(60)$ \\
$\mathrm{CV}: E_{1 / 2} / \mathrm{V}\left(\Delta E_{\mathrm{p}} / \mathrm{mV}\right)^{\mathrm{c}}$ & $-0.11(470)$ & $0.13(330)$ \\
$\Lambda_{\mathrm{M}}^{\mathrm{d}} / \Omega^{-1} \mathrm{~cm}^{2} \mathrm{M}^{-1}$ & 128 & 190 \\
$\mu_{\mathrm{efff}}^{\mathrm{e}} / \mu \mathrm{B}$ & 1.78 & 1.75 \\
$K_{\mathrm{a}}^{\mathrm{f}} / \mathrm{M}^{-1}$ & $1.8 \times 10^{3}$ & $8.28 \times 10^{5}$ \\
$K_{\mathrm{b}}^{\mathrm{g}} / \mathrm{M}^{-1}$ & & $3.58( \pm 0.2) \times 10^{5}$ \\
{$[s]$} & & {$[1.53( \pm 0.1)]$} \\
$\Delta T_{\mathrm{m}}^{\mathrm{h}} /{ }^{\circ} \mathrm{C}$ & & $2.0( \pm 0.1)$ \\
\hline
\end{tabular}

${ }^{\text {a }} \mathrm{KBr}$ phase.

b In aqueous medium.

${ }^{\mathrm{c}} \mathrm{Cu}(\mathrm{II}) / \mathrm{Cu}(\mathrm{I})$ couple in Tris-buffer-0.1 M KCl. $E_{1 / 2}=0.5\left(E_{\mathrm{pa}}+E_{\mathrm{pc}}\right)$, $\Delta E_{\mathrm{p}}=E_{\mathrm{pa}}-E_{\mathrm{pc}}$, where $E_{\mathrm{pa}}$ and $E_{\mathrm{pc}}$ are the anodic and cathodic peak potentials, respectively. Scan rate: $50 \mathrm{mV} \mathrm{s}^{-1}$.

${ }^{\mathrm{d}}$ In aqueous medium.

e $\mu_{\text {eff }}$ for solid at $298 \mathrm{~K}$.

f Apparent DNA binding constant from competitive binding assay by emission method.

g DNA binding constant from absorption spectral method.

${ }^{\mathrm{h}}$ Increase in melting temperature of CT DNA.

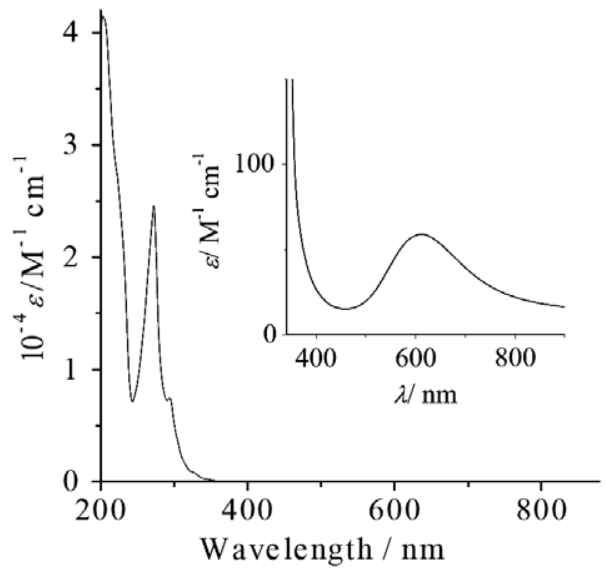

Fig. 1. Electronic spectrum of complex $\mathbf{2}$ in an aqueous medium. The inset shows the $\mathrm{d}-\mathrm{d}$ band of the complex 2 .

cule (average trigonal distortion parameter, $\tau_{\mathrm{av}}=0.094$ ) [36]. The structure resembles to the corresponding structure of reported $\left[\mathrm{Cu}(\mathrm{L}-\mathrm{pro})(\right.$ phen $\left.)\left(\mathrm{H}_{2} \mathrm{O}\right)\right]\left(\mathrm{NO}_{3}\right)$ complex [24]. The configuration at the proline nitrogen and the $\alpha$-carbon is $S$ in each complex cation. The copper atom is displaced by $\sim 0.16 \AA$ from the mean plane through its basal atoms in the direction towards the apical water molecule. The conformation of the five-membered ring of the proline ligand can be described as twisted. The ORTEP view of the molecule is shown in Fig. 2. Selected bond distances and angles are given in Table 2.

The bpy structure shows extensive intermolecular noncovalent interactions. While one hydrogen atom of the aqua ligand in $\mathbf{1}$ is hydrogen-bonded to the oxygen atom of the lattice nitrate anion (distance $2.816 \AA$ ), the other hydrogen atom is $\mathrm{H}$-bonded with the carboxylate oxygen atom of another molecule $($ distance $=2.696 \AA$ ). One more intermolecular hydrogen bond persists between hydrogen atom of secondary amine nitrogen of proline and oxygen

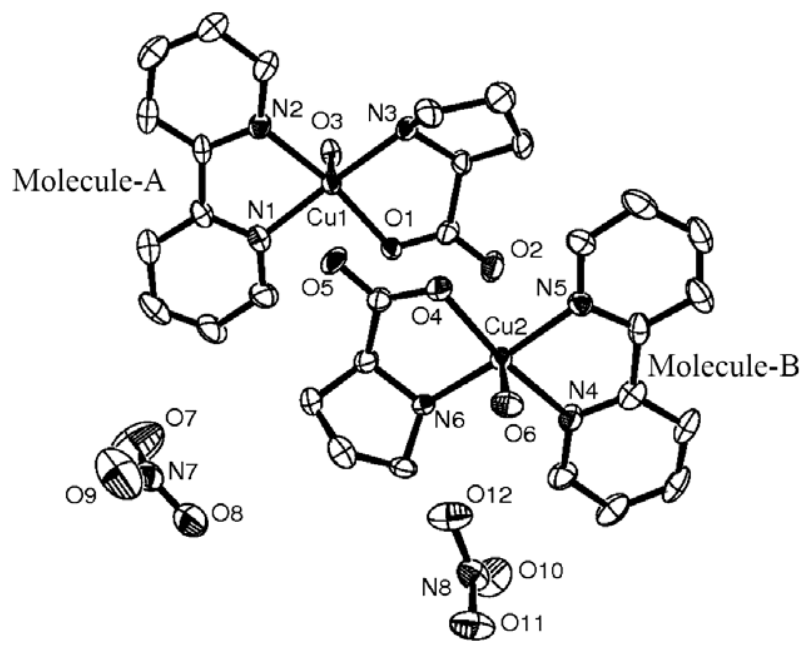

Fig. 2. ORTEP diagram of two independent molecules of complex 1 showing $50 \%$ probability thermal ellipsoids with atom labeling scheme for the metal and heteroatoms. 
Table 2

Selected bond distances $(\AA)$ and angles $\left({ }^{\circ}\right)$ for $[\mathrm{Cu}(\mathrm{L}-$ pro $)(\mathrm{bpy})-$ $\left.\left(\mathrm{H}_{2} \mathrm{O}\right)\right]\left(\mathrm{NO}_{3}\right)(\mathbf{1})$

\begin{tabular}{lrlr}
\hline Molecule-A & \multicolumn{3}{l}{ Molecule-B } \\
\hline $\mathrm{Cu}(1)-\mathrm{N}(1)$ & $1.963(8)$ & $\mathrm{Cu}(2)-\mathrm{N}(4)$ & $2.023(8)$ \\
$\mathrm{Cu}(1)-\mathrm{N}(2)$ & $2.005(7)$ & $\mathrm{Cu}(2)-\mathrm{N}(5)$ & $2.010(7)$ \\
$\mathrm{Cu}(1)-\mathrm{N}(3)$ & $2.011(6)$ & $\mathrm{Cu}(2)-\mathrm{N}(6)$ & $1.994(6)$ \\
$\mathrm{Cu}(1)-\mathrm{O}(1)$ & $1.938(6)$ & $\mathrm{Cu}(2)-\mathrm{O}(4)$ & $1.934(6)$ \\
$\mathrm{Cu}(1)-\mathrm{O}(3)$ & $2.330(6)$ & $\mathrm{Cu}(2)-\mathrm{O}(6)$ & $2.271(5)$ \\
$\mathrm{N}(1)-\mathrm{Cu}(1)-\mathrm{N}(2)$ & $81.2(3)$ & $\mathrm{N}(4)-\mathrm{Cu}(2)-\mathrm{N}(5)$ & $80.3(3)$ \\
$\mathrm{N}(1)-\mathrm{Cu}(1)-\mathrm{N}(3)$ & $177.2(3)$ & $\mathrm{N}(4)-\mathrm{Cu}(2)-\mathrm{O}(4)$ & $167.9(3)$ \\
$\mathrm{N}(1)-\mathrm{Cu}(1)-\mathrm{O}(1)$ & $92.8(3)$ & $\mathrm{N}(4)-\mathrm{Cu}(2)-\mathrm{O}(6)$ & $93.0(3)$ \\
$\mathrm{N}(1)-\mathrm{Cu}(1)-\mathrm{O}(3)$ & $91.2(2)$ & $\mathrm{N}(4)-\mathrm{Cu}(2)-\mathrm{N}(6)$ & $98.9(3)$ \\
$\mathrm{N}(2)-\mathrm{Cu}(1)-\mathrm{N}(3)$ & $100.6(3)$ & $\mathrm{N}(5)-\mathrm{Cu}(2)-\mathrm{N}(6)$ & $168.7(3)$ \\
$\mathrm{N}(2)-\mathrm{Cu}(1)-\mathrm{O}(1)$ & $167.2(3)$ & $\mathrm{N}(5)-\mathrm{Cu}(2)-\mathrm{O}(4)$ & $92.9(3)$ \\
$\mathrm{N}(2)-\mathrm{Cu}(1)-\mathrm{O}(3)$ & $96.9(2)$ & $\mathrm{N}(5)-\mathrm{Cu}(2)-\mathrm{O}(6)$ & $90.0(2)$ \\
$\mathrm{N}(3)-\mathrm{Cu}(1)-\mathrm{O}(1)$ & $84.8(3)$ & $\mathrm{N}(6)-\mathrm{Cu}(2)-\mathrm{O}(4)$ & $85.8(3)$ \\
$\mathrm{N}(3)-\mathrm{Cu}(1)-\mathrm{O}(3)$ & $90.7(2)$ & $\mathrm{N}(6)-\mathrm{Cu}(2)-\mathrm{O}(6)$ & $101.2(2)$ \\
$\mathrm{O}(1)-\mathrm{Cu}(1)-\mathrm{O}(3)$ & $94.6(2)$ & $\mathrm{O}(4)-\mathrm{Cu}(2)-\mathrm{O}(6)$ & $97.1(2)$ \\
\hline
\end{tabular}

atom of lattice nitrate anion (distance $3.013 \AA$ ). The unit cell packing diagram of $\mathbf{1}$ shown in Fig. S1. The intermolecular hydrogen bonding interactions present in $\mathbf{1}$ are shown in Fig. S2.

\subsection{DNA binding properties}

The binding of the complexes $\mathbf{1}$ and $\mathbf{2}$ to the calf thymus (CT) DNA has been studied by electronic absorption spectral technique. The absorption spectral traces of the complex 2 with increasing concentration of CT DNA are shown in Fig. 3. We have observed minor bathochromic shift of $3 \mathrm{~nm}$ along with significant hypochromicity for complex 2. The equilibrium DNA binding constants $\left(K_{\mathrm{b}}\right)$ along with binding site size $(s)$ determination of the complexes to CT DNA are obtained by monitoring the change of the absorption intensity of the spectral bands with increasing concentration of CT DNA. The bpy complex

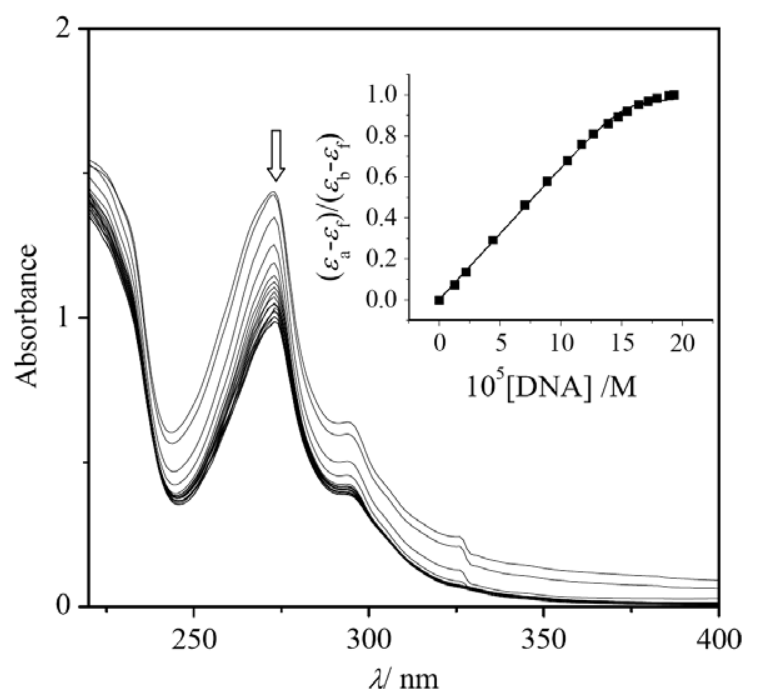

Fig. 3. Absorption spectral traces on addition of CT DNA to the solution of 2 (shown by arrow). The inset shows the best least-squares fit of $\Delta \varepsilon_{\mathrm{af}} /$ $\Delta \varepsilon_{\text {bf }}$ vs. [DNA]. shows weak binding to the DNA due to less extended planarity compared to phen, which is consistent with the observed trend in hypochromism. $K_{\mathrm{b}}$ and $s$ values for the phen complex, 2 are $3.58( \pm 0.2) \times 10^{5} \mathrm{M}^{-1}$ and 1.53 $( \pm 0.1)$, respectively. The higher binding propensity of the phen complex in comparison to its bpy analogue could be due to the presence of extended planar aromatic ring in phen. Earlier studies on bis-phen copper complex have shown that this complex binds to DNA either by partial intercalation or binding of one phen ligand to the minor groove while the other phen making favourable contacts within the groove [37-40]. The nature of binding of the phen complex is proposed to be similar as observed for the bis-phen species.

The emission spectral method is used to study the relative binding of the complexes to CT-DNA. The emission intensity of ethidium bromide (EB) is used as a spectral probe as EB shows no apparent emission intensity in buffer solution because of solvent quenching and an enhancement of the emission intensity when intercalatively bound to DNA [41]. The binding of the complexes to DNA decreases the emission intensity of EB. Relative binding propensity of the complexes to DNA is measured from the extent of reduction of the emission intensity (Fig. 4). The apparent binding constant $\left(K_{\text {app }}\right)$ values for $\mathbf{1}$ and $\mathbf{2}$ are $1.8 \times 10^{3}$ and $8.28 \times 10^{5} \mathrm{M}^{-1}$, respectively. The comparatively high DNA binding propensity of the phen complex in comparison to its bpy analogue could be due to the presence of extended aromatic ring in planar phen ligand facilitating non-covalent interactions with the DNA molecule. The reduction of the emission intensity of EB on increasing the complex concentration could be due to displacement of the DNA bound EB by the ternary copper(II) complexes.

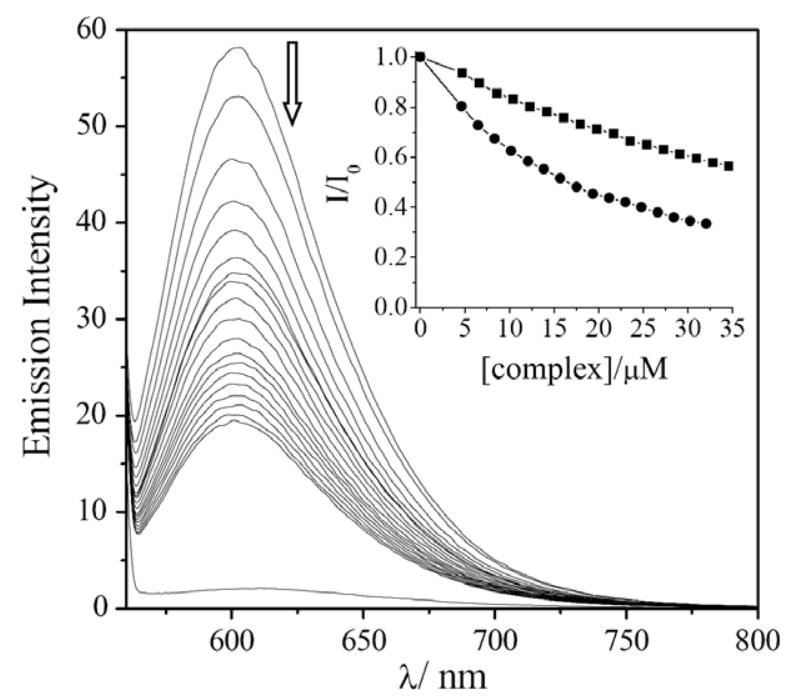

Fig. 4. Emission spectral changes on addition of $[\mathrm{Cu}(\mathrm{L}-$ pro)(phen)$\left.\left(\mathrm{H}_{2} \mathrm{O}\right)\right]\left(\mathrm{NO}_{3}\right)(2)$ to the CT-DNA bound to ethidium bromide (shown by arrow). Inset: Effect of addition of $\left[\mathrm{Cu}(\mathrm{L}-\mathrm{pro})(\mathrm{B})\left(\mathrm{H}_{2} \mathrm{O}\right)\right]\left(\mathrm{NO}_{3}\right)[\mathrm{B}=$ bpy $(\mathbf{1}$, -); phen $(2,0)]$ to the emission intensity of $300 \mu \mathrm{M}$ CT DNA-bound ethidium bromide $(1.3 \mu \mathrm{M})$ in a $5 \mathrm{mM}$ Tris- $\mathrm{HCl} / 5 \mathrm{mM} \mathrm{NaCl}$ buffer $(\mathrm{pH}$ 7.2) at $25^{\circ} \mathrm{C}$. 
The denaturation of DNA from double-strand to single strand results in absorption hyperchromism around $260 \mathrm{~nm}$. The binding of metal complexes to the doublestranded DNA usually stabilizes the duplex structure to some extent depending on the strength of interaction with nucleic acid [42]. The binding should lead to an increase in the melting temperature $\left(T_{\mathrm{m}}\right)$ of DNA as compared to DNA itself. The binding of the complex 2 results in an moderate increase $\left(\sim 2{ }^{\circ} \mathrm{C}\right)$ in the melting temperature $\left(\Delta T_{\mathrm{m}}\right)$ of CT-DNA suggesting primarily electrostatic and/or groove binding nature of the complexes (Table 1, Fig. 5a).

To investigate further the binding modes of the complexes, viscosity measurements on solutions of calf thymus DNA incubated with the complexes were carried out. Because the viscosity of a DNA solution is sensitive to the addition of organic drugs and metal complexes bound by intercalation, we examined the effect on the specific relative viscosity of DNA upon addition of complexes. Since the relative specific viscosity $\left(\eta / \eta_{0}\right),\left(\eta\right.$ and $\eta_{0}$ are the specific viscosities of DNA in the presence and absence of the complexes, respectively) of DNA reflects the increase in contour length associated with separation of DNA base pairs caused by intercalation, a classical intercalator such as EtBr could cause a significant increase in viscosity of DNA solutions. In contrast, a partial and/or non-classical intercalation of the ligand could bend or kink DNA resulting in a decrease in its effective length with a concomitant increase in its viscosity $[43,44]$. The plots of relative viscosities with $\mathrm{R}=[\mathrm{Cu}] /[\mathrm{DNA}]$ are shown in Fig. $5 \mathrm{~b}$. The relative viscosity of DNA increases with increase in the concentration of the complex $\mathbf{2}$ but less compared to that of potential classical intercalators, e.g. ethidium bromide. This is consistent with the observed trend by other optical methods and suggesting primarily electrostatic and/or groove binding nature of the complex.

\subsection{DNA cleavage studies}

The oxidative DNA cleavage activity of the complexes in the presence of reducing agent 3-mercaptopropionic acid
(MPA, $5 \mathrm{mM}$ ) is investigated by agarose gel electrophoresis using supercoiled (SC) plasmid pUC19 DNA $(0.2 \mu \mathrm{g}$, $33.3 \mu \mathrm{M} \mathrm{NP}$ ) in $50 \mathrm{mM}$ Tris- $\mathrm{HCl} / 50 \mathrm{mM} \mathrm{NaCl}$ buffer (pH 7.2) and the copper(II) complexes (Fig. 6). Selected DNA cleavage data are given in Table 3 . The phen complex 2 shows efficient "chemical nuclease" activity. A $30 \mu \mathrm{M}$ complex shows complete conversion of the SC (form I) to its nicked-circular form (NC, form II) of DNA. Control experiments with MPA or the ternary complexes alone do not show any apparent conversion of $\mathrm{SC}$ to its nicked-circular (NC) form. The bpy complex is cleavage inactive due to its poor binding ability to DNA. To determine the groove binding preference of $\mathbf{2}$, control experiments have been carried out in the presence of minor groove binder distamycin-A $[45,46]$. Inhibition of cleavage in presence of distamycin-A for the phen complex, suggesting minor groove binding preference for the phen complex.

Mechanistic aspects of the chemical nuclease reactions are performed using various control experiments (Fig. 6). It is observed that hydroxyl radical scavengers [47] like catalase, DMSO, KI significantly inhibit the DNA cleavage activity of the complex $\mathbf{2}$ indicating the possibility of the involvement of hydroxyl radical and/or "copper-oxo" intermediate as the reactive species. Addition of superoxide dismutase (SOD) does not show any inhibitory effect on the cleavage activity suggesting the non-involvement of $\mathrm{O}_{2}{ }^{-{ }^{-}}$in

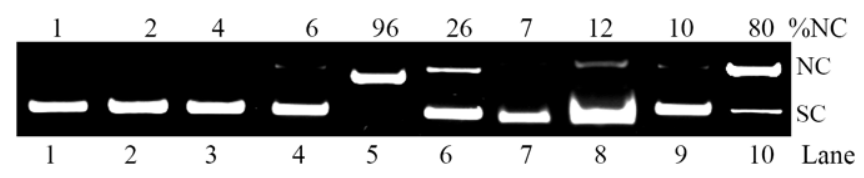

Fig. 6. Gel electrophoresis diagram showing the cleavage of SC pUC19 DNA $(0.2 \mu \mathrm{g}, 33.3 \mu \mathrm{M})$ by complexes 1 and $2(30 \mu \mathrm{M})$ in $50 \mathrm{mM}$ Tris$\mathrm{HCl} / 50 \mathrm{mM} \mathrm{NaCl}$ buffer $(\mathrm{pH} 7.2)$ in the presence of MPA $(5 \mathrm{mM})$ : Lane 1, DNA control; Lane 2, DNA + L-pro $(30 \mu \mathrm{M})+\mathrm{MPA}$; Lane 3, DNA + 2; Lane 4, DNA + 1 + MPA; Lane 5, DNA + 2+ MPA; Lane 6, DNA + distamycin-A $(100 \mu \mathrm{M})+\mathbf{2}+\mathrm{MPA} ;$ Lane 7, DNA + DMSO $(4 \mu \mathrm{L})+\mathbf{2}+\mathrm{MPA} ;$ Lane 8 , DNA + catalase $(4 \mathrm{U})+\mathbf{2}+$ MPA; Lane 9 , $\mathrm{DNA}+\mathrm{KI} \quad(100 \mu \mathrm{M})+\mathbf{2}+\mathrm{MPA} ; \quad$ Lane $10, \quad \mathrm{DNA}+\mathrm{SOD}$ $(4 \mathrm{U})+2+$ MPA.
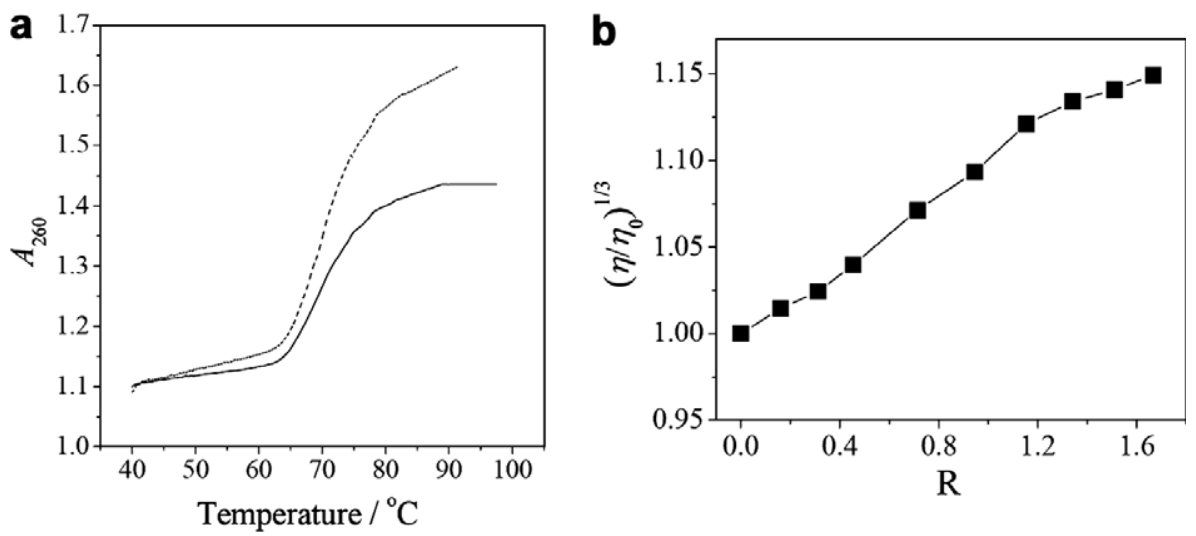

Fig. 5. (a) DNA melting curves for CT-DNA in the absence (- - ) and presence of complex 2 (-). (b) Changes in the relative viscosity of the CT DNA $(200 \mu \mathrm{M})$ on increasing concentration of complex 2 at $37.0( \pm 0.1)^{\circ} \mathrm{C}$ in $5 \mathrm{mM}$ Tris $-\mathrm{HCl}$ buffer $(\mathrm{pH} 7.2), \mathrm{R}=[\mathrm{complex}] /[\mathrm{DNA}]$. 
Table 3

Selected cleavage data of SC pUC19 $(0.2 \mu \mathrm{g}, 33.3 \mu \mathrm{M} \mathrm{NP})$ by complexes 1 and $\mathbf{2}^{\mathrm{a}}$

\begin{tabular}{|c|c|c|c|}
\hline Sl. No. & Reaction condition & {$[$ Complex $] / \mu \mathrm{M}$} & $\% \mathrm{NC}$ \\
\hline 1 & $\mathrm{DNA}+\mathrm{MPA}(5 \mathrm{mM})$ & & 1 \\
\hline 2 & DNA + L-proline $(30 \mu \mathrm{M})+$ MPA & & 2 \\
\hline 3 & $\mathrm{DNA}+\mathbf{2}$ & 30 & 4 \\
\hline 4 & $\mathrm{DNA}+\mathbf{1}+\mathrm{MPA}$ & 30 & 6 \\
\hline 5 & $\mathrm{DNA}+\mathbf{2}+\mathrm{MPA}$ & 30 & 96 \\
\hline 6 & $\mathrm{DNA}+$ distamycin- $^{\mathrm{b}}+\mathbf{2}+\mathrm{MPA}$ & 30 & 26 \\
\hline 7 & $\mathrm{DNA}+\mathrm{DMSO}^{\mathrm{c}}+\mathbf{2}+\mathrm{MPA}$ & 30 & 7 \\
\hline 8 & DNA + catalase $^{\mathrm{d}}+\mathbf{2}+\mathrm{MPA}$ & 30 & 12 \\
\hline 9 & $\mathrm{DNA}+\mathrm{KI}^{\mathrm{e}}+\mathbf{2}+\mathrm{MPA}$ & 30 & 10 \\
\hline 10 & $\mathrm{DNA}+\mathrm{SOD}^{\mathrm{f}}+\mathbf{2}+\mathrm{MPA}$ & 30 & 80 \\
\hline
\end{tabular}

${ }^{\mathrm{a}} \mathrm{NC}$ is nicked-circular form of DNA. [MPA] $=5 \mathrm{mM}$.

b $100 \mu \mathrm{M}$.

c $4 \mu \mathrm{L}$.

d 4 units.

e $100 \mu \mathrm{M}$

f 4 units.

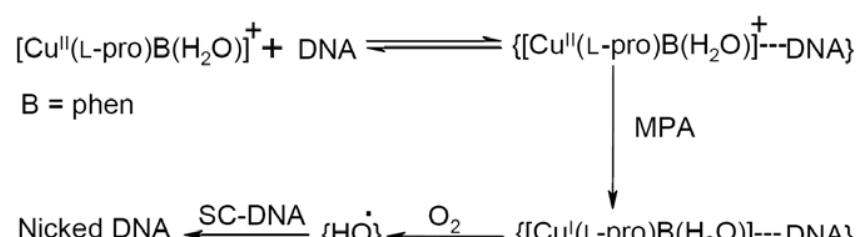

Scheme 2. Proposed mechanistic pathway for the chemical nuclease activity of complex $\mathbf{2}$ in Tris-buffer medium.

the cleavage reaction. The pathways involved in the DNA cleavage reactions are believed to be analogous to those proposed by Sigman and co-workers for the chemical nuclease activity of bis(phen)copper species (Scheme 2) $[1,39,40]$.

\section{Conclusions}

Two ternary copper(II) complexes having N,O-donor $\alpha$ amino acid L-proline and $\mathrm{N}, \mathrm{N}$-donor heterocyclic bases are prepared and characterized. The copper(II) complex with planar phenanthroline base in $\mathrm{CuN}_{3} \mathrm{O}_{2}$ coordination geometry shows efficient DNA binding ability. The complex shows minor groove binding propensity. The study also confirms that the binding ability of the complexes is important to achieve efficient DNA cleavage activity. Significant chemical nuclease activity is observed for the phen complex 2 under physiological reaction conditions via a mechanistic pathway involving formation of hydroxyl radicals in presence of the MPA.

\section{Acknowledgements}

The authors gratefully acknowledge the support of Prof. Akhil R. Chakravarty, Department of Inorganic and Physical Chemistry, Indian Institute of Science, in providing facilities and useful discussions. Financial support received from the Department of Science and Technology (DST, SR/S5/BC-14/2006), Government of India, is gratefully acknowledged. R.K. is thankful to the Indian Academy of Sciences for a summer research fellowship. A.K.P. is thankful to CSIR for a fellowship. Thanks are due to the Alexander von Humboldt Foundation, Germany, for donation of an electroanalytical system; the Convener, Bioinformatics Center, Indian Institute of Science, Bangalore, for a database search; and the DST for the CCD diffractometer facility.

\section{Appendix A. Supplementary material}

CCDC 648241 contains the supplementary crystallographic data for $\mathbf{1}$. These data can be obtained free of charge via http://www.ccdc.cam.ac.uk/conts/retrieving. html, or from the Cambridge Crystallographic Data Centre, 12 Union Road, Cambridge CB2 1EZ, UK; fax: (+44) 1223-336-033; or e-mail: deposit@ccdc.cam.ac.uk. Supplementary data associated with this article can be found, in the online version, at doi:10.1016/j.poly.2007. 07.040 .

\section{References}

[1] D.S. Sigman, A. Mazumder, D.M. Perrin, Chem. Rev. 93 (1993) 2295.

[2] D.S. Sigman, Acc. Chem. Res. 19 (1986) 180.

[3] B. Meunier, Chem. Rev. 92 (1992) 1411.

[4] A.M. Pyle, J.K. Barton, Prog. Inorg. Chem. 38 (1990) 413.

[5] K.E. Erkkila, D.T. Odom, J.K. Barton, Chem. Rev. 99 (1999) 2777.

[6] B. Armitage, Chem. Rev. 98 (1998) 1171.

[7] D.R. McMillin, K.M. McNett, Chem. Rev. 98 (1998) 1201.

[8] W.K. Pogozelski, T.D. Tullius, Chem. Rev. 98 (1998) 1089.

[9] H.T. Chifotides, K.R. Dunbar, Acc. Chem. Res. 38 (2005) 146.

[10] E.R. Jamieson, S.J. Lippard, Chem. Rev. 99 (1999) 2467.

[11] M. Sabat, in: A. Sigel, H. Sigel (Eds.), Metal Ions in Biological Systems, vol. 32, Marcel Dekker, New York, Basel, 1996.

[12] (a) A.R. Chakravarty, P.A.N. Reddy, B.K. Santra, A.M. Thomas, Proc. Ind. Acad. Sci. (Chem. Sci.) 114 (2002) 391;

(b) B.K. Santra, P.A.N. Reddy, G. Neelkanta, S. Mahadevan, M. Nethaji, A.R. Chakravarty, J. Inorg. Biochem. 89 (2002) 191;

(c) A.M. Thomas, G. Neelkanta, S. Mahadevan, M. Nethaji, A.R. Chakravarty, Eur. J. Inorg. Chem. (2002) 2720;

(d) A.M. Thomas, M. Nethaji, S. Mahadevan, A.R. Chakravarty, J. Inorg. Biochem. 94 (2003) 171;

(e) P.A.N. Reddy, M. Nethaji, A.R. Chakravarty, Eur. J. Inorg. Chem. (2004) 1440.

[13] S. Dhar, P.A.N. Reddy, M. Nethaji, S. Mahadevan, M.K. Saha, A.R. Chakravarty, Inorg. Chem. 41 (2002) 3469.

[14] R. Pradhan, A.M. Thomas, A. Mukherjee, S. Dhar, M. Nethaji, A.R. Chakravarty, Indian J. Chem. 44A (2005) 18.

[15] (a) A.K. Patra, S. Dhar, M. Nethaji, A.R. Chakravarty, Chem. Commun. (2003) 1562;

(b) A.K. Patra, S. Dhar, M. Nethaji, A.R. Chakravarty, Dalton Trans. (2005) 896;

(c) A.K. Patra, M. Nethaji, A.R. Chakravarty, Dalton Trans. (2005) 2798;

(d) A.K. Patra, M. Nethaji, A.R. Cakravarty, J. Inorg. Biochem. 101 (2007) 233.

[16] H. Li, X.-Y. Le, D.-W. Pang, H. Deng, Z.-H. Xu, Z.-H. Lin, J. Inorg. Biochem. 99 (2005) 2240. 
[17] S. Zhang, Y. Zhu, C. Tu, H. Wei, Z. Yang, L. Lin, J. Ding, J. Zhang, Z. Guo, J. Inorg. Biochem. 98 (2004) 2099.

[18] Y. Jin, J. Cowan, J. Am. Chem. Soc. 127 (2005) 8408.

[19] F.V. Pamatong, C.A. Detmer III, R. Bocarsly, J. Am. Chem. Soc. 118 (1996) 5339.

[20] R. Ren, P. Yang, W. Zheng, Z. Hua, Inorg. Chem. 39 (2000) 5454.

[21] A. García-Raso, J.J. Fiol, B. Adrover, V. Moreno, I. Mata, E. Espinosa, E. Molins, J. Inorg. Biochem. 95 (2003) 77.

[22] A. Yaron, F. Naider, Crit. Rev. Biochem. Mol. Biol. 28 (1993) 31.

[23] D.D. Perrin, W.L.F. Armarego, D.R. Perrin, Purification of Laboratory Chemicals, Pergamon Press, Oxford, UK, 1980.

[24] (a) R. Venkatraman, J.D. Zubkowski, E.J. Valente, Acta Crystallogr., Sect. C C55 (1999) 1241;

(b) P. Sgarabotto, F. Bisceglie, G. Pelosia, L.A. Rahman, Polyhedron 18 (1999) 2505.

[25] O. Khan, Molecular Magnetism, VCH, Weinheim, 1993.

[26] G.M. Sheldrick, SADABS Version 2 Multi-Scan Absorption Correction Program, University of Göttingen, Germany, 2001.

[27] G.M. Sheldrick, shelx 97 Programs for Crystal Structure Solution and Refinement, University of Göttingen, Göttingen Germany, 1997.

[28] M.N. Burnett, C.K. Johnson, ORTEP-III Report ORNL-6895, Oak Ridge National Laboratory, Oak Ridge, TN, 1996.

[29] J. Marmur, J. Mol. Biol. 3 (1961) 208.

[30] M.E. Reichmann, S.A. Rice, C.A. Thomas, P. Doty, J. Am. Chem. Soc. 76 (1954) 3047.

[31] J.D. McGhee, P.H. von Hippel, J. Mol. Biol. 86 (1974) 469.

[32] (a) R.B. Nair, E.S. Teng, S.L. Kirkland, C.J. Murphy, Inorg. Chem. 37 (1998) 139;

(b) M.T. Carter, M. Rodriguez, A.J. Bard, J. Am. Chem. Soc. 111 (1989) 8901; (c) D.L. Carlson, D.H. Huchital, E.J. Mantilla, R.D. Sheardy, W.R. Murphy Jr., J. Am. Chem. Soc. 115 (1993) 6424

[33] J.-B. LePecq, C. Paoletti, J. Mol. Biol. 27 (1967) 87.

[34] S. Neidle, Nat. Prod. Rep. 18 (2001) 291.

[35] J. Bernadou, G. Pratviel, F. Bennis, M. Girardet, B. Meunier, Biochemistry 28 (1989) 7268.

[36] A.W. Addison, T.N. Rao, J.V. Reedijk, G.C. Verschoor, J. Chem. Soc., Dalton Trans. (1984) 1349.

[37] J.M. Veal, R.L. Rill, Biochemistry 30 (1991) 132.

[38] J.M. Veal, K. Merchant, R.L. Rill, Nucleic Acids Res. 19 (1991) 3383.

[39] O. Zelenko, J. Gallagher, D.S. Sigman, Angew. Chem., Int. Ed. Engl. 36 (1997) 2776.

[40] D.S. Sigman, Biochemistry 29 (1990) 9097.

[41] J.M. Kelly, A.B. Tossi, D.J. McConnel, C. OhUigin, Nucleic Acids Res. 13 (1985) 6017.

[42] M. Lee, A.L. Rhodes, M.D. Wyatt, S. Forrow, J.A. Hartley, Biochemistry 32 (1993) 4237.

[43] S. Satyanarayana, J.C. Dabrowiak, J.B. Chaires, Biochemistry 31 (1992) 9319

[44] T. Hirohama, Y. Kuranuki, E. Ebina, T. Sugizaki, H. Arii, M. Chikira, P.T. Selvi, M. Palaniandavar, J. Inorg. Biochem. 99 (2005) 1205.

[45] C. Bailly, J.B. Chaires, Bioconjugate Chem. 9 (1998) 513.

[46] M. Coll, C.A. Frederick, A.H.-J. Wang, A. Rich, Proc. Natl. Acad. Sci. USA 84 (1987) 8385.

[47] (a) O.I. Aruoma, B. Halliwell, M. Dizdaroglu, J. Biol. Chem. 264 (1989) 13024;

(b) S.M. Klein, G. Cohen, A.I. Cederbaum, Biochemistry 20 (1981) 6006. 